\title{
Professional Identity in Private Hospital
}

\author{
Abdul Haeba Ramli*, Arsil, Rowlan Takaya \\ Master of Management \\ Universitas Trisakti \\ Jakarta, Indonesia \\ *abdul.haeba@trisakti.ac.id
}

\author{
Siti Mariam \\ Institut Ilmu Sosial dan Manajemen STIAMI \\ Jakata, Indonesia
}

\begin{abstract}
The employee Health are part of the public health work force in Bekasi, and its shortage has been identified as an urgent priority that should be addressed. Turnover is one of the main contributors to the shortage problem. This research assessed the influence of Perceived Organizational Support and professional identity on turnover intention of The Employee Health and explored the intermediary effect of professional identity between Perceived Organizational Support and turnover intention in private hospital The employee Health in Bekasi. Data were collected from 206 health employee in Jabar Province, Bekasi city. We used structural equation modeling (SEM) to test the hypothesized relationship among the variables. Results showed that Professional Organizational Support had a direct negative effect on turnover intention ( $t$-statistic $=1.98$, $t$-table $<$ 1.65), Professional Organizational Support had a direct positive effect on Professional Identity (t-statistic $=5.09$, t-table $<1.65$ ), and Perceived Organizational Support had an indirect positive effect on turnover intention through the mediating effect of professional identity. Our results strongly confirmed that Perceived Organizational Support and professional identity were strong predicators of turnover intention. According to the results, desirable work environment, quality facilities, fair compensation and adequate advancement opportunities should be emphasized to improve Professional Identity. The turnover intention of health employee could be reduced through improving professional identity, enhancing Professional Organizational Support.
\end{abstract}

Keywords-perceived organizational support, professional identity and turnover intention

\section{INTRODUCTION}

In the health news published in Radar Bekasi [1] there was an increase in the number of hospitals to 64 hospitals. the challenge of quality service in Indonesian Hospitals is in line with the development of the business world in the current service sector. Making the sixth Indonesian Non-Government Hospital Association (ARSSI) hold a series of annual agendas in the form of a national seminar VI, this time carrying the theme "Challenges of Indonesian Hospitals in the Industrial Age 4.0 and Universal Health Coverage". Rapid changes in industry 4.0 triggered creative ideas of technology and services that made disruption or fundamental changes in the future survival of the nation's children [2]. The management of Rawalumbu hospital is encouraged to create improvements in all areas of service so that it can quickly respond to the needs of modern society and in accordance with the demands of the current era. The hospital has become a place for smart and safe treatment services in overcoming disruptive situations (disruption) and running global health coverage or Universal Health Coverage (UHC) which is a boost in the future. in this case, financial difficulties are not an excuse for not being able to seek treatment.

Human resources (HR) are very influential in order to realize competition and overall business performance. Because, $\mathrm{HR}$ is one of the centers of attention in the business world, namely ensuring the existence and implementation of all organizational desires [3]. The Ministry of Health (2009) has informed through Law 44 of 2009 [4], that hospitals are health care institutions for the people with their own characteristics that are influenced by the advancement of health science, technological developments, and social and economic life of the people who are certainly still able to provide quality services that are affordable and affordable for the people to ensure optimal health levels. We chose Rawalumbu Hospital as a research site because it is in Bekasi and is the largest hospital in the Rawalumbu sub-district of Bekasi City, so that it can represent the population of private hospitals in Bekasi City. The Gillies method (1994) [5] explains that labor turnover is considered standard at $5-10 \%$ per year, if it exceeds $10 \%$ it is declared high. The following is the data on the admission and turnover of hospital health personnel for the period of 2016 to 2019 at Rawalumbu hospital:

TABLE I. NUMBER OF EMPLOYEES TURNOVER DURING 2016-2019

\begin{tabular}{|c|c|c|c|c|}
\hline \multirow{2}{*}{ Year } & \multirow{2}{*}{$\begin{array}{c}\text { Total } \\
\text { Employees }\end{array}$} & \multicolumn{2}{|c|}{ Employees } & \multirow{2}{*}{$\begin{array}{c}\text { Percentage } \\
(\%)\end{array}$} \\
\hline & & in & out & \\
\hline 2016 & 264 & 60 & 74 & 29 \\
\hline 2017 & 262 & 39 & 41 & 15 \\
\hline 2018 & 225 & 36 & 73 & 22 \\
\hline 2019 & 230 & 45 & 41 & 19 \\
\hline
\end{tabular}

Source: Head of Bekasi Private Hospital HR Department (2019)

Table 1, shows the range of high employee turnover developments from 2016 to 2019 (until September). Employee turnover has led to an increase over the past three years. The highest turnover index number occurred in January 2016 with a total of 74 people, then the number of two in 2018 which amounted to 73 people. Hospitals that have employees with 
high Turnover Intention can result in performance decreasing, due to the low ability to carry out tasks properly. So that the resulting task can damage the image of the hospital and finally the hospital management does not have competent paramedics to their duties and need to hold new training again [6]. The work left by paramedics is a loss that must be borne by the policy bearers in the hospital [7].

This research is very important in order to find out the causes of the number of Turnover Intention in hospitals and to reduce spending, as well as the negative impact on hospital management. Turnover Intention (IT) has many factors, including Perceived Organization Support (POS), but lack of focus in analyzing [8]. Organizational support theory is the way employees look at how hospital management provides valuable use and Job Satisfaction commitments [9] and a slight effect on them leaving the organization [8]. Then Eisenberger and Huntington [10], said Perceived Organization Support described employees as forming global trusts related to how much organizations care about the welfare and values they contribute. According to the results of Ahmed [11] research, it is revealed that Perceived Organization Support indirectly helps satisfied employees to remain with the organization.

Professional Identity is related to work, two terms that must be separated, namely profession and professional. A profession is a position or an officer who has certain expertise. According to Hassan and Waffa [12] there is a statistically significant negative correlation of Professional Identity and Turnover Intention. Zhang and Meng [13], said the main contribution of their research was the role of Professional Identity because it was related to Turnover Intention. So Perceived Organization Support is positively related to Professional Identity.

So, in this research the writer will look at the extent of the effect of Perceived Organization Support on Turnover Intention with Professional Identity as a mediating variable, which is different from the research of Lin et al [14] who observed how the effect of workplace violence on Turnover Intention with Perceived Organizational Support, Job Satisfaction as a mediating variable. A description of the results of research by Simone Planta [15] about observing the role of Job Satisfaction in Turnover Intention in nurses and patients, while the results of research conducted by Zhang et al [13] only see the influence of Professionals Identity towards Turnover Intention with Job Satisfaction as a mediating variable. This research involves employees as respondents and will be conducted at Rawalumbu Hospital in Rawalumbu Sub-District, Bekasi City.

\section{LITERATURE REVIEW}

\section{A. Perceived Organization Support (POS)}

In exploring employee relations with organizations, many studies have focused their attention on Perceived Organizational Support which is defined as the general impression of health workers about the extent to which their organizations value their contributions and care for their wellbeing. According Eisenberger and Stinglhamber [16],
Perceived Organizational Support is a message of health workers that management appreciates their participation in the organization, so that it has been proven to have important benefits for employees and employers. The study found that employees with high Perceived Organizational Support, suffered less stress at work and were more likely to return to work recovered more quickly [17]. High Perceived Organizational Support is positively related to performance [18].

\section{B. Professional Identity (PI)}

Identity according to Ting-Toomey [19] is a picture of individuals who come from the family environment, gender, culture, ethnicity and socialization process. Identity is a reflection of the individual and other people's impressions of us. While Larry [20] see identity as a description of one's self as a person who is different in behavior, beliefs and attitudes. Identity is described as a coherent narrative about the life of a person that is built and reconstructed in relation to various external and internal factors across time and space. In contrast, in social constructivist accounts. Vygotsky Identity symbolizes the process by which people try to integrate their various statuses and roles [21], as well as their diverse experiences, into a coherent self-image [22]. Wenger defines identity as what we know, what is foreign and what we choose to know, and how we know it [23].

Our identity determines with whom we will interact in knowledge sharing activities, and our willingness and capacity to engage in boundary interactions [23]. Barker said that theoretically Identity itself is a matter of similarity and differences in individual and social aspects [24], about the similarity of individuals to a number of people and items that are not the same as someone with another person.

\section{Turnover Intention}

Malna et al explain the willingness to move as an individual's tendency to actually leave an organization [25]. According to Noe [3], avoiding work situations by unsatisfied individuals is a series of attitudes taken to withdraw from work responsibilities. So Turnover Intention is described as a voluntary willingness to stop working from one work place to another at their own choice [26]. Based on some of the explanations above, it can be concluded that Turnover Intention is a desire of someone in a conscious condition without any compulsion to be outside or not to be part of the organization that can be preceded by various reasons to trigger desires.

According to Agung et al [27] and Ramli [28] states Turnover Intention refers to the conscious and deliberate desire to leave the organization. Freely meant that Turnover Intention refers to the conscious and deliberate desire to leave the organization. Human resources expert [3]. argues that turnover is formed from a level of dissatisfaction that occurs continuously which is then triggered by disruptive events in the workplace that encourage employees not to get along with others (eg disputes with superiors or coworkers) or who encourage employees to engage in unhelpful activities outside 
of work because they eliminate an unpleasant atmosphere (alternative to coming home from work).

\section{Hypothesis Development Research}

According to Liu et al [14] conducted a study that Perceived Organizational Support had a significant negative impact on turnover intentions. Hospitals must understand the importance of Perceived Organizational Support and establish a reasonable incentive system to reduce Turnover Intention. The contribution of Perceived Organizational Support will greatly reduce the willingness of health workers to leave the hospital [29].

H1: There is a negative and significant effect of Perceive Organization Support on Turnover Intentions.

Professional Identity is influenced by Perceived Organization Support. The creation of a professional work empowerment system is an opportunity to create Perceived Organization Support, in the eyes of health workers. This system proves that organizational support makes a real contribution in developing Professional Identity. The research of John et al [30] found that Perceived Organization Support was related to empowering work and contributing to the empowerment of health workers who could simultaneously increase Job Satisfaction of health workers as one of the Professionals.

$\mathrm{H} 2$ : There is a positive and significant effect of Perceive Organization Support on Professional Identity.

Professional Identity includes the use of all knowledge, skills and abilities of health workers with clear definitions of boundaries with other professions. Professional Identity can empower health workers to reflect additional roles that are responsible and fair, change the traditional approach of how health workers feel themselves and be felt by others, develop related thoughts about Professional Identity [31]. Being a professional contributes to the formation of confidence and effective communication, it can immunize nurses against bladder, humility and discrimination at work, so that professional identity can help in reducing turnover. The results of Rahab and Waffa [32] show that Professional Identity has a negative and significant influence on the Turnover Intention of health workers.
H3: There is a negative and significant effect Professional Identity on Turnover Intention.

Hospitals recognize the role of health workers and pay attention to their future, so the level of meaning of Perceived Organizational Support is understood by employees according to Robbins et al [33]. Similar to Caessens et al [34] said the social exchange approach to show the correlation between health workers and hospitals is a conclusion of Perceived Organizational Support. In the end, health workers admit that the encouragement provided by the hospital is very appropriate to replace them with a commitment to be able to make the appropriate contribution to the progress they serve. The results of the Ahmed [11] show that Professional Identity provides a negative and significant correlation to Turnover Intention.

H4: There is a negative and significant effect of Perceive Organization Support on Turnover Intentions mediated by Professional Identity.

\section{METHODS}

Structural Equation Model (SEM) statistical analysis tools with SmartPLS (Partial Least Square) software are used in measurement models (outer models), structural models (inner models) and hypothesis testing. The population in this study conducted in September to December 2019 at the Private Hospital located in Bekasi is a health worker, consisting of: doctors, nurses, midwives, operators, pharmacy staff, admn / and others. Sampling itself is carried out using the Slovin method, after being entered into the Slovin formula, so that the minimum number of samples is 146 (one hundred forty-six) [35]. The number of questionnaires distributed was 300. The questionnaires returned were incomplete by prospective respondents as many as 9 (nine) and 15 (fifteen) returned but were not filled in, so that the questionnaires that had been returned to the author and filled out were 206 (two hundred and six).

\section{RESULTS AND DISCUSSION}

\section{A. Results}

1) Hypothesis testing: The results of data processing are carried out to test the hypothesis, as described in Table 2 below:

TABle II. Path CoefFicients (Mean, St.DeV, T-Values)

\begin{tabular}{|c|c|c|c|}
\hline Hypothesis & $\begin{array}{c}\text { Original } \\
\text { Sample (O) }\end{array}$ & $\begin{array}{l}\text { t- Statistics } \\
(\mid \text { O/STERR })\end{array}$ & Decision \\
\hline $\begin{array}{l}\text { H1: There is a negative and significant effect of Perceive Organization Support on } \\
\text { Turnover Intentions. }\end{array}$ & -0.270575 & 1.986809 & Negative Significant \\
\hline $\begin{array}{l}\text { H2: There is a positive and significant effect of Perceive Organization Support on } \\
\text { Professional Identity. }\end{array}$ & 0.435991 & 5.097172 & Positive -Significant \\
\hline $\begin{array}{l}\text { H3: There is a negative and significant effect Professional Identity on Turnover } \\
\text { Intention. }\end{array}$ & 0.131193 & 1.060546 & Positive Significant \\
\hline $\begin{array}{l}\text { H4: There is a negative and significant effect of Perceive Organization Support on } \\
\text { Turnover Intentions mediated by Professional Identity. }\end{array}$ & 0.5374 & 1.96 & $\begin{array}{l}\text { Positive and not } \\
\text { Significant }\end{array}$ \\
\hline
\end{tabular}

Source: data processed 


\section{B. Discussion}

The first hypothesis, based on the results of data processing for testing the effect obtained negative original sample value $=$ -0.27 and a significance value ( $\mathrm{t}$-statistic value) of 1.98 . So that shows that Perceived Organizational Support has a negative and significant effect on Turnover Intention. Thus the first hypothesis is accepted

The second hypothesis, based on the results of data processing for testing the effect obtained positive original sample value $=0.43$ and the significance value $(\mathrm{t}$-statistic value) of 5.09. So that shows that Perceived Organizational Support has a positive and significant effect on Professional Identity. Thus the second hypothesis is accepted.

The third hypothesis, based on the results of data processing for testing the effect obtained positive original sample value $=0.13$ but the significance value (t-statistic value) of 1.06 (smaller than z-table 1.96). So that shows that Professional Identity has a positive but not significant effect on Turnover Intention. Thus the third hypothesis is rejected.

The fourth hypothesis, based on the results of data processing for testing the effect of mediation from Professional Identity, the z-calculated value $=0.537$ (greater than $\mathrm{z}$-table $=$ 1.96 ) with a positive coefficient $=0.08$. So that shows that Professional Identity mediates a positive but insignificant influence Perceived Organizational Support on Turnover Intention. Thus the fourth hypothesis is rejected.

\section{CONCLUSION}

Based on the findings and testing of hypotheses that have been explained, several conclusions can be drawn from the results of this study: (1) There is a negative and significant effect of Perceived Organizational Support on Turnover Intention. (2) There is a positive and significant effect Perceived Organizational Support on Professional Identity (3) There is a negative but not significant effect of Professional Identity on Turnover Intention. (4) And there is a positive and not significant influence of Perceived Organizational Support on Turnover Intention through Professional Identity.

The results of this study helps management to determine the direction of policy towards the management of human resources, especially in the field of health services to reduce Turnover Intention and provide attention and care through Perceived Organizational Support to employees who provide health services such as Hospitals, which is it become a major factor of moving forward in fierce business competition.

Either by conducting open communication and entertainment on a regular basis or by means of regular rewards so that employees are able to increase the level of Professional Identity, so they can assess their abilities, assess the effects of their work, and be able to use and manage Professional Identity properly in work. They can get this to make a real contribution to Rawalumbu hospital.
Because this research proves that if employees already have a high level of Professional Identity, thus their optimal performance will be obtained. Suggestions that can be given to future researchers to add more supporting variables that form the Solid Organization, so that it enriches the findings about the factors that influence the Turnover Intention, for example with the variable Work Passion [36], Job Satisfaction [7] and Organizational Justice [37]. This research was conducted only on health services industry such as hospitals, perhaps future researchers could further develop other research on other service industries, manufacturing industries, and others.

\section{REFERENCES}

[1] Anonim, "RS Penerima KS Dipangkas," 2020

[2] S. Setiawaty, "Rumah Sakit Swasta harus Berinovasi untuk Penuhi Tuntutan Konsumen, Ini Alasannya," 2019.

[3] R. Noe, Fundamentals of Human Resource Management 8th Edition. Ohio : McGraw-Hill Education, 2019.

[4] A.P.K. Masyarakat, "UU 44 Tahun 2009," 2009. http://kesmas.kemkes.go.id/perpu/konten/uu/uu-nomor-44-tahun-2009ttg-rs

[5] D.A. Gillies, "Manajemen keperawatan: suatu pendekatan sistem, Edisi ke Tiga," Terjemahan, Philadelphia WB Saunder Co., 1994.

[6] M.H.R. Joarder, M.Y. Sharif, and K. Ahmmed, "Mediating role of affective commitment in HRM practices and turnover intention relationship: A study in a developing context.,” Bus. Econ. Res. J., vol. 2 , no. 4,2011

[7] A.F. Mahdi, M.Z.M. Zin, M.R.M. Nor, A.A. Sakat, and A.S.A. Naim, "The relationship between job satisfaction and turnover intention," Am. J. Appl. Sci., vol. 9, no. 9, p. 1518, 2012

[8] Z. Ahmed, M. Rizwan, M. Ahmad, and M. Haq, "Effect of brand trust and customer satisfaction on brand loyalty in Bahawalpur," J. Sociol. Res., vol. 5, no. 1, pp. 306-326, 2014.

[9] A.H. Ramli, "The mediator role of leader-member exchange in empirical test," J. Manaj. dan Pemasar. Jasa, vol. 13, no. 1, pp. 127-136, 2020.

[10] R. Eisenberger, R. Huntington, S. Hutchison, and D. Sowa, "Perceived organizational support.," J. Appl. Psychol., vol. 71, no. 3, p. 500, 1986.

[11] A.I. Hunjra, M. Ijaz, D. Chani, M. Irfan, and U. Mustafa, "Impact of dividend policy, earning per share, return on equity, profit after tax on stock prices," Hunjra, AI, Ijaz, M. S, Chani, MI, Hassan, S. Mustafa, U.(2014). Impact Divid. Policy, Earn. per Share, Return Equity, Profit after Tax Stock Prices. Int. J. Econ. Empir. Res., vol. 2, no. 3, pp. 109$115,2014$.

[12] A.E. Wafaa, "Professional Identity and Turnover Intention among Staff Nurses in Different," IOSR J. Nurs. Heal. Sci. e-ISSN 2320-1959. pISSN 2320-1940 Vol. 6, Issue 3 Ver. III (May.-June. 2017), PP 00-00, 2017

[13] W. Zhang, H. Meng, S. Yang, and D. Liu, "The influence of professional identity, job satisfaction, and work engagement on turnover intention among township health inspectors in China," Int. J. Environ. Res. Public Health, vol. 15, no. 5, p. 988, 2018.

[14] W. Liu, S. Zhao, L. Shi, Z. Zhang, X. Liu, L. Li, X. Duan, G. Li, F. Lou and X. Jia, "Workplace violence, job satisfaction, burnout, perceived organisational support and their effects on turnover intention among Chinese nurses in tertiary hospitals: a cross-sectional study," BMJ Open, vol. 8, no. 6, 2018.

[15] S. De Simone, A. Planta, and G. Cicotto, "The role of job satisfaction, work engagement, self-efficacy and agentic capacities on nurses' turnover intention and patient satisfaction," Appl. Nurs. Res., vol. 39, pp. 130-140, 2018. 
[16] R. Eisenberger and F. Stinglhamber, Perceived organizational support: Fostering enthusiastic and productive employees. American Psychological Association, 2011.

[17] C.L. Shaw, G.D.R. Watson, H.L. Hallock, K.M. Cline, and A.L. Griffin, "The role of the medial prefrontal cortex in the acquisition, retention, and reversal of a tactile visuospatial conditional discrimination task," Behav. Brain Res., vol. 236, pp. 94-101, 2013.

[18] J.N. Kurtessis, R. Eisenberger, M.T. Ford, L.C. Buffardi, K.A. Stewart, and C.S. Adis, "Perceived organizational support: A meta-analytic evaluation of organizational support theory," J. Manage., vol. 43, no. 6, pp. 1854-1884, 2017.

[19] Ting-Toomey, Identity Negotiation Theory, Identity Negotiation Theory 2005.

[20] L.A. Samovar, E.R. Porter, E.R. McDaniel, and C.S. Roy, "Communication between Cultures-Cengage Learning," Bost. Wadsworth, 2013.

[21] L.S. Vygotsky, Mind in society: The development of higher psychological processes. Harvard university press, 1980.

[22] N.B. Epstein, C.E. Ryan, D.S. Bishop, I.W. Miller, and G.I. Keitner, The McMaster model: A view of healthy family functioning. The Guilford Press, 2003.

[23] E. Wenger, R.A. McDermott, and W. Snyder, Cultivating communities of practice: A guide to managing knowledge. Harvard Business Press, 2002.

[24] C. Barker, Cultural studies: Teori \& praktik. Kreasi Wacana, 2004.

[25] M.A. Malna, R. Rodhiyah, and R.S. Dewi, "Pengaruh Kompensasi dan Motivasi Kerja Terhadap Turnover Intention Melalui Stress Kerja Karyawan PT. Bank Tabungan Negara Kantor Cabang Semarang," J. Ilmu Adm. Bisnis, vol. 4, no. 1, pp. 154-165, 2015.

[26] S. Indah Komala, "Hubungan Mutu Pelayanan Keperawatan dengan Kepuasan Pasien di Ruang Rawat Inap RSUD dr. Rasidin Padang Tahun 2014." Universitas Andalas, 2015.

[27] A.A.W.S. Waspodo, N.C. Handayani, and W. Paramita, "Pengaruh kepuasan kerja dan stres kerja terhadap turnover intention pada karyawan pt. Unitex di bogor," JRMSI-Jurnal Ris. Manaj. Sains Indones., vol. 4, no. 1, pp. 97-115, 2013.

[28] A.H. Ramli, "Person-Organization Fit dalam Rantai Distribusi Pemasaran,” J. Manaj. dan Pemasar. Jasa, vol. 12, no. 1, pp. 77-92, 2019.

[29] Y. Ariani, R. Sitorus, and D. Gayatri, "Hubungan antara motivasi dengan efikasi diri pasien DM tipe 2 dalam konteks asuhan keperawatan di RSUP. H. Adam Malik Medan," Unpubl. master's thesis) Univ. Indones. Depok, Indones., 2011.

[30] J.R. Hollenbeck, R.A. Noe, P.M. Wright, and B. Gerhart, Human Resource Management 11th Edition, Kindle Edition, 11th ed. McGrawHill Higher Education, 2018.

[31] E.E. Friberg and J.L. Creasia, Conceptual Foundations-E-Book: The Bridge to Professional Nursing Practice. Elsevier Health Sciences, 2013.

[32] Rabab M. Hassan dan Wafaa A. Elhosany, Professional Identity and Turnover Intention among Staff Nurses in Different. 2017.

[33] S.P. Robbins, "Dan Timothy A. Judge. 2015,” Organ. Behav., vol. 15.

[34] G. Caesens, F. Stinglhamber, S. Demoulin, M. De Wilde, and A. Mierop, "Perceived organizational support and workplace conflict: The mediating role of failure-related trust," Front. Psychol., vol. 9, p. 2704, 2019.

[35] N. Setiawan, "Penentuan ukuran sampel memakai rumus slovin dan tabel krejcie-morgan: telaah konsep dan aplikasinya," Univ. Padjadjaran. Bandung, 2007.

[36] S. Mariam and A.H. Ramli, "The effect of work passion, work engagement, and job satisfaction on turnover intention (Empirical study: PT. Bank Mandiri (Persero) Tbk)," in The 1st International Conference on Business, Accounting, Supply Chain and Logistics, 2019, p. 219.

[37] R. Kumar, C. Ramendran, and P. Yacob, “A study on turnover intention in fast food industry: Employees' fit to the organizational culture and the important of their commitment," Int. J. Acad. Res. Bus. Soc. Sci., vol. 2, no. 5, pp. 9-42, 2012. 